\title{
Effect of Temperature on Symptom Expression and Reliability of Banana Streak Badnavirus Detection in Naturally Infected Plantain and Banana (Musa spp.)
}

\author{
G. Dahal, J. d'A. Hughes, and G. Thottappilly, International Institute of Tropical Agriculture (IITA), Oyo Road, \\ PMB 5320, Ibadan, Nigeria; International mailing address: IITA, c/o L. W. Lambourn \& Co., Carolyn House, 26 \\ Dingwall Road, Croydon CR9 3EE, UK; and B. E. L. Lockhart, Department of Plant Pathology, University of \\ Minnesota, St. Paul 55108
}

\begin{abstract}
Dahal, G., Hughes, J. d'A., Thottappilly, G., and Lockhart, B. E. L. 1998. Effect of temperature on symptom expression and reliability of banana streak badnavirus detection in naturally infected plantain and banana (Musa spp.). Plant Dis. 82:16-21.

The effect of temperature on symptom expression and detection of banana streak badnavirus (BSV) by immunosorbent electronmicroscopy (ISEM) and enzyme-linked immunosorbent assay of 12 in vitro-propagated plantain hybrids (genome $\mathrm{AAB} \times \mathrm{AA}$ ), $3 \mathrm{ABB}$ cooking banana, and 3 $\mathrm{AAB}$ plantain landraces was studied. Experiments were done for 2 years under two temperature regimes, 28 to $35^{\circ} \mathrm{C}$ in a screenhouse and $22^{\circ} \mathrm{C}$ in a temperature-controlled room. Most BSVinfected plants of plantain hybrids expressed symptoms under both conditions. Symptom expression was enhanced when plants were continuously grown at $22^{\circ} \mathrm{C}$, but later became indiscernible when plants were continuously grown at 28 to $35^{\circ} \mathrm{C}$. Plants grown at $22^{\circ} \mathrm{C}$ and showing severe symptoms contained significantly higher virus titer than plants grown at 28 to $35^{\circ} \mathrm{C}$. When asymptomatic plants with very low virus titer at 28 to $35^{\circ} \mathrm{C}$ were transferred back to $22^{\circ} \mathrm{C}$, there was a significant increase in both symptom severity and concentration of virus (greater than 3 to 5 times) in leaf tissues after 9 months. In contrast, the concentration of virus and symptom severity decreased in plants after transfer from $22^{\circ} \mathrm{C}$ to 28 to $35^{\circ} \mathrm{C}$. Micropropagated plants of AAB plantain landrace cv. Mimi Abue and ABB cooking bananas (cvs. Bluggoe, Cardaba, and Pelipita) did not express visible symptoms under either temperature regime, but BSV was detected by ISEM in $23 \%$ of the plants. After 2 years at $22^{\circ} \mathrm{C}$, virus was detected in $64 \%$ of the plants, but the concentration of virus remained low. Implications of these results on quarantine screening of in vitro plants and virus diagnosis are discussed.
\end{abstract}

Additional keywords: badnavirus detection, Musa badnavirus, symptomatology

Plantain and banana are grown in more than 120 countries (6), providing a significant source of carbohydrate for more than 400 million people in tropical countries (22). In recent years, banana streak disease (16) has been recognized as a serious constraint to successful produc-

Present address of first author: Department of Plant Pathology, University of Minnesota, St. Paul 55108; E-mail: gdahal@ puccini.crl.umn.edu

This study was supported by grants from the World Bank/FAO Common Fund for Commodities on Banana Improvement Program, and from the International Network for Improvement of Banana and Plantain.

Submitted as paper No. IITA/97/JA/12.

Accepted for publication: 22 September 1997.

Publication no. D-1997-1105-01R

This article is in the public domain and not copyrightable. It may be freely reprinted with customary crediting of the source. The American Phytopathological Society, 1998. tion of plantain and banana in sub-Saharan Africa (16,21).

Banana streak disease, caused by banana streak virus (BSV; Genus: Badnavirus), was first identified from Morocco in 1986 (10). Since then, it has been reported from many countries of Africa including Benin, Cote d'Ivoire, Ghana, Malawi, Nigeria, Rwanda, and Tanzania $(14,18,24)$ as well as from Asia, Latin America (Colombia), and Australia $(5,9,19)$. BSV has bacilliform particles (30 by 130 to $150 \mathrm{~nm} ; 10$ ), and a circular dsDNA genome of $7.4 \mathrm{kbp}(11,8)$. Five serologically distinct isolates have been identified so far from Costa Rica, Honduras, Morocco, Rwanda, and Trinidad $(14,15)$. Serological variants of BSV also occur in Nigeria (B. E. L. Lockhart, unpublished data) but have not been characterized. However, all these isolates can be detected using a cocktail of BSV antiserum by immunosorbent electron microscopy (ISEM; 1) and triple-antibody sandwich enzyme-linked immunosorbent assay (TAS-ELISA; 15). BSV is serologically closely related to sugarcane bacilliform badnavirus (13).
In Morocco, BSV-infected banana (Musa spp. [AAA group] cv. Dwarf Cavendish) had broken or continuous streaks and/or sparse or concentrated spindleshaped lesions on leaf lamina (10) which often turned necrotic upon aging. The initial chlorotic symptoms superficially resembled those caused by cucumber mosaic cucumovirus (CMV). However, spindleshaped lesions caused by CMV do not turn necrotic (9). In Nigeria, a diverse range of symptoms associated with BSV-infected banana and plantain hybrids (genome $\mathrm{ABB}$ $\times \mathrm{AA}$ and genome $\mathrm{AAB} \times \mathrm{AA})$ include distortion of the leaf lamina, necrotic cigar leaf, distorted bunch or fruits, and necrotic pseudostem $(4,7)$. Results of multilocational field experiments conducted during 1991 to 1994 at 10 locations in Nigeria and Cameroon showed that symptom expression was more severe under cool environments $\left(28\right.$ to $30^{\circ} \mathrm{C}$ ) but was not apparent in the hot, dry season $\left(30\right.$ to $\left.35^{\circ} \mathrm{C} ; 4,7,17\right)$. The precise correlation between symptom appearance and/or severity and temperature changes has not been experimentally determined. Identification of factors responsible for symptom expression is important, as detection is more reliable from symptomatic than from asymptomatic samples (12). The objective of this study was to determine the effect of temperature on symptom expression and BSV detection on some naturally infected plantain and banana.

\section{MATERIALS AND METHODS}

Plant material and virus isolates. BSV-negative plants of plantain hybrids and cooking bananas, as indexed by immunosorbent electronmicroscopy (ISEM), were selected for micro-propagation and established in pots (23). They included 11 tetraploid plantain hybrids and 1 tetraploid banana hybrid $(\mathrm{AAB} \times \mathrm{AA}$ group with code TMPx and $\mathrm{ABB} \times \mathrm{AA}$ group with code TMBX, respectively; hereafter called plantain hybrids), 3 ABB cooking bananas, and 3 AAB plantain landraces. These plants were maintained in an insect-proof screenhouse $\left(28\right.$ to $\left.35^{\circ} \mathrm{C}\right)$ or a temperaturecontrolled coolroom at $22^{\circ} \mathrm{C}$ (hereafter called coolroom) with the final aim of 
selecting "BSV-negative" plants. Three separate experiments were conducted and the effect of growth conditions (particularly temperature) on expression of BSV symptoms on plantain hybrids and cooking bananas was studied.

The BSV isolate we used was found in naturally infected plantain hybrids from the International Institute of Tropical Agriculture (IITA), Onne station, in Nigeria (18).
The naturally infected plants were micropropagated (23) and grown in screenhouse and coolrooms at Ibadan, Nigeria. The genome of the BSV in these plants has been shown to be similar to other badnaviruses (8).

Assessment of symptoms. Since BSV causes different symptoms in Musa genotypes under natural conditions (4), observations were made on types of symptoms expressed by micropropagated plants under screenhouse and coolroom growth conditions. To quantify symptom severity, individual leaves were scored at weekly or fortnightly intervals on a 0 to 3 scale (4), where $0=$ no visible symptoms, $1=$ very few (less than $10 \%$ of leaf area) streaks or chlorotic flecks on the leaf lamina, $2=$ streaks or chlorotic flecks covering a moderate portion (10 to $50 \%$ ) of the leaves, and

Table 1. Symptomatology and immunosorbent electronmicroscopy (ISEM) indexing of banana streak badnavirus (BSV) in 11 Musa hybrids and 1 plantain landrace grown under screenhouse $\left(28\right.$ to $\left.35^{\circ} \mathrm{C}\right)$ and coolroom $\left(22 \pm 2{ }^{\circ} \mathrm{C}\right)$ conditions at Ibadan, Nigeria

\begin{tabular}{|c|c|c|c|c|c|c|c|c|c|}
\hline \multirow[b]{3}{*}{ Genotypes } & \multicolumn{4}{|c|}{ Initial coolroom treatment } & \multirow{2}{*}{\multicolumn{2}{|c|}{12 months after transfer to screenhouse }} & \multirow{2}{*}{\multicolumn{3}{|c|}{4 months after transfer to coolroom }} \\
\hline & \multirow[b]{2}{*}{$\begin{array}{l}\text { Symptoms }^{\mathrm{w}} \\
\text { (2-10 months) }\end{array}$} & \multicolumn{3}{|c|}{ No. infected (ISEM) ${ }^{\mathrm{v}}$} & & & & & \\
\hline & & $\begin{array}{c}4 \\
\text { months }\end{array}$ & $\begin{array}{c}7 \\
\text { months }\end{array}$ & $\begin{array}{c}10 \\
\text { months }\end{array}$ & $\begin{array}{c}\text { Symptoms }^{\mathrm{w}} \\
(2-22 \text { months })\end{array}$ & $\begin{array}{l}\text { No. Infected } \\
\text { (ISEM) }\end{array}$ & $\begin{array}{l}\text { Symptoms }^{\mathrm{w}} \\
\text { (2-26 months) }\end{array}$ & $\begin{array}{c}\text { Absorbance }^{\mathrm{x}} \\
\left(A_{405 \mathrm{~nm}}\right)\end{array}$ & $\begin{array}{c}\text { No. infected } \\
\text { (ELISA) }^{\mathrm{y}}\end{array}$ \\
\hline TMPx 548-4 & Ns & $0 / 2^{x}$ & $2 / 2$ & $2 / 2$ & Chls-Ns & $0 / 2$ & Ns & 0.134 & $0 / 2$ \\
\hline TMPх 548-9 & Chls & $1 / 3$ & $2 / 3$ & $3 / 3$ & $\mathrm{~S}-\mathrm{Ns}^{y}$ & $2 / 3$ & Ns & 0.448 & $1 / 2$ \\
\hline TMPx 612-74 & Ns & $0 / 2$ & $1 / 2$ & $2 / 2$ & S-Ns & $1 / 2$ & Ns & 0.312 & $1 / 2$ \\
\hline TMPx 582-4 & Ns & $0 / 2$ & $1 / 2$ & $2 / 2$ & S-Ns & $1 / 2$ & Ns & 0.096 & $0 / 1$ \\
\hline TMPx 1621-1 & Ns & $0 / 2$ & $2 / 2$ & $2 / 2$ & S-Ns & $\ldots^{\mathrm{z}}$ & Ns & 0.129 & $0 / 1$ \\
\hline TMPх 1658-4 & Ns & $0 / 2$ & $2 / 2$ & $2 / 2$ & S-Ns & $0 / 2$ & Ns & 0.443 & $1 / 1$ \\
\hline TMPx 2481 & Ns & $0 / 4$ & $4 / 4$ & $4 / 4$ & S-Ns & $0 / 4$ & Ns & 0.170 & $0 / 1$ \\
\hline TMPx 2796-5 & Ns & $0 / 2$ & $2 / 2$ & $2 / 2$ & S-Ns & $0 / 2$ & Ns & 0.279 & $1 / 1$ \\
\hline TMPx 4698-1 & Chls & $3 / 4$ & $4 / 4$ & $4 / 4$ & Chls-Ns & $0 / 4$ & Chls & $0.23-1.0$ & $3 / 4$ \\
\hline TMPx 5511-2 & Ns & $2 / 4$ & $3 / 4$ & $4 / 4$ & S-Ns & $0 / 4$ & Ns & $0.38-0.81$ & $4 / 4$ \\
\hline TMBх 612-74 & Ns & $0 / 2$ & $1 / 2$ & $2 / 2$ & S-Ns & $0 / 1^{z}$ & Ns & 0.278 & $1 / 2$ \\
\hline Obino l'Ewai & Ns & $0 / 2$ & $1 / 2$ & $2 / 2$ & S-Ns & $0 / 2$ & Ns & 0.545 & $1 / 2$ \\
\hline Overall & & $6 / 31$ & $25 / 31$ & $31 / 31$ & & $4 / 28$ & & & $13 / 23$ \\
\hline (\%) & & 19.3 & 80.6 & 100.0 & & 14.3 & & & 56.5 \\
\hline
\end{tabular}

${ }^{v}$ Number BSV-positive plants/total number of plants tested by ISEM.

${ }^{\mathrm{w}}$ Symptoms were observed at monthly interval. Chls = chlorotic streaks; Ns = no visible symptoms; S-Ns = occasional streaks to no apparent symptoms.

After transfer to the screenhouse, most plants expressed dark streaks (S), mostly at the leafbase, which became indiscernible after 4 to 5 months.

${ }^{x}$ Absorbance value $\left(A_{405 \mathrm{~nm}}\right)$ of symptomless ISEM-negative (control) ranged 0.058 to 0.133 (average 0.108 ) and positive control was 1.723 ; absorbances higher than the twice the mean negative value are in bold and presented in range.

${ }^{y}$ Number of BSV-positive plants/total number of plants tested by ELISA.

${ }^{\mathrm{z}}$ One plant was left in the cool room for a further micropropagation experiment.

Table 2. Banana streak badnavirus (BSV) indexing by immunosorbent electronmicroscopy (ISEM) and enzyme-linked immunosorbent assay (ELISA) of $\mathrm{BSV}$ in 5 cooking banana and 1 plantain hybrid grown under screenhouse ( $\mathrm{SH}, 28$ to $\left.35^{\circ} \mathrm{C}\right)$ and coolroom $\left(\mathrm{CR}, 22 \pm 2{ }^{\circ} \mathrm{C}\right)$ conditions at Ibadan, Nigeria

\begin{tabular}{|c|c|c|c|c|c|}
\hline \multirow[b]{3}{*}{ Genotype (genome) } & \multirow[b]{3}{*}{ Growth condition } & \multirow[b]{3}{*}{ Plant no. } & \multicolumn{3}{|c|}{ BSV indexing } \\
\hline & & & \multicolumn{2}{|c|}{ ISEM score } & \multirow{2}{*}{$\begin{array}{c}\text { ELISA }\left(A_{405 n m}\right)^{y} \\
26 \text { months } \\
\end{array}$} \\
\hline & & & 9 months & 21 months & \\
\hline Agbagba & $\mathrm{SH}$ & 1 & 2 & 0 & 0.216 \\
\hline$(\mathrm{AAB})$ & $\mathrm{CR}$ & 2 & 2 & 1 & 0.262 \\
\hline Mimi Abue & SH & 1 & 1 & 1 & 0.190 \\
\hline \multirow{3}{*}{$(\mathrm{AAB})$} & & 2 & 0 & 0 & 0.189 \\
\hline & $\mathrm{CR}$ & 3 & 0 & 0 & 0.075 \\
\hline & & 4 & 0 & 1 & 0.612 \\
\hline Bluggoe & $\mathrm{SH}$ & 1 & 0 & 0 & 0.146 \\
\hline \multirow[t]{2}{*}{$(\mathrm{ABB})$} & $\mathrm{CR}$ & 2 & 0 & 0 & 0.126 \\
\hline & & 3 & 0 & 0 & 0.137 \\
\hline Cardaba & SH & 1 & 0 & 0 & 0.138 \\
\hline \multirow{3}{*}{ (ABB) } & & 2 & 0 & 0 & 0.106 \\
\hline & $\mathrm{CR}$ & 3 & 0 & 0 & 0.122 \\
\hline & & 4 & 0 & 1 & 0.162 \\
\hline Pelipita & SH & 1 & 0 & 0 & 0.109 \\
\hline \multirow[t]{3}{*}{$(\mathrm{ABB})$} & & 2 & 0 & 0 & 0.127 \\
\hline & $\mathrm{CR}$ & 3 & 0 & 1 & 0.114 \\
\hline & & 4 & 0 & 1 & 0.162 \\
\hline TMPх 7002-1 & SH & 1 & 2 & 0 & NT \\
\hline \multirow[t]{3}{*}{$(\mathrm{AAB} \times \mathrm{AA})$} & & 2 & 1 & 0 & 0.290 \\
\hline & $\mathrm{CR}$ & 3 & 1 & 1 & 0.335 \\
\hline & & 4 & 1 & 1 & 0.227 \\
\hline \multirow[t]{2}{*}{ Overall } & $\mathrm{SH}$ & 11 & $4 / 11(36.4)^{\mathrm{z}}$ & $1 / 11(9.1)$ & $1 / 10(10.0)$ \\
\hline & $\mathrm{CR}$ & 11 & $3 / 11(23.3)$ & $7 / 11(63.6)$ & $4 / 11(36.4)$ \\
\hline
\end{tabular}

${ }^{y}$ Absorbance $\left(A_{405 \mathrm{~nm}}\right)$ of symptomless ISEM-negative plants (control) ranged from 0.089 to 0.112 (average 0.109 ), and positive control was 2.712 . Absorbances higher than twice the mean negative control value are in bold and on borderline in italics. NT $=$ not tested.

${ }^{\mathrm{z}}$ Plants with BSV-positive/total number of plants; figures in parentheses are percentages. 
$3=$ most of the leaf lamina (more than $50 \%$ ) covered with streaks or chlorotic flecks. Symptom severity index (SSI) was calculated from the severity score of individual leaves as SSI $=(0[a]+1[b]+2[c]+$ $3[\mathrm{~d}]) / n$, where $\mathrm{a}, \mathrm{b}, \mathrm{c}$, and $\mathrm{d}$ are the number of leaves with scores $0,1,2$, and 3 respectively, and $n$ is the total number of leaves (4). The mean SSI value of all plants within a genotype was used as an average symptom severity index (ASSI) of each genotype. Association of symptoms with BSV was confirmed by ISEM and/or (ELISA).

ISEM. BSV indexing by ISEM was done using partially purified extracts (minipreps) using anti-BSV immunoglobulin- $\mathrm{G}(\mathrm{IgG})$ to trap virus particles as described by Ahlawat et al. (1). For virion quantification, counts were ranked on a 0 to 6 scale, where $0=$ no particles seen in 5 random squares of a 400 mesh grid viewed at $8000 \times$ magnification; $1=$ fewer than 1 particle per field; $2=1$ to 5 particles; $3=5$ to 10 particles; $4=10$ to 20 particles; and 5 $=$ more than 20 particles per field of view.

ELISA. Double-antibody sandwich (DAS)-TAS-ELISA procedures (B. E. L. Lockhart, unpublished; 15) were followed to quantify the BSV concentration in plant extracts. A small portion of tissue was taken from 3 to 4 mature, fully expanded leaves (except from oldest and unfolding "cigar leaf") and pooled into a composite sample (about 2 to $3 \mathrm{~g}$ ). Tissue was ground in phosphate-buffered saline (PBS; 100 $\mathrm{mM}$ phosphate [pH 7.0], containing $2 \%$ $\mathrm{NaCl}, 1 \% \mathrm{Na}_{2} \mathrm{SO}_{3}$ and $0.05 \%$ Tween-20). Microtiter plates coated with $1 \mu \mathrm{g} / \mathrm{ml}$ BSV IgG, and trapped BSV antigens were detected by BSV IgG-alkaline phosphatase conjugate at 1:2000 to 1:4000. Absorbance $\left(A_{405 \mathrm{~nm}}\right)$ values greater than twice the mean value (at least four wells) of negative controls but greater than 0.1 were considered positive.

Experiment 1. Thirty micropropagated plants from 11 plantain hybrids and $1 \mathrm{AAB}$ cooking banana (Obino l'Ewai) were grown in the coolroom containment facility (Table 1). Two to four plants per genotype were arranged in a randomized complete block design. After 10 months, 1 plant each of TMPx 1621-1 and TMBx 612-74 remained in the coolroom throughout the study period for observation; however, all other plants were moved to the screenhouse, grown for 1 year, then moved back to coolroom conditions. Composite leaf samples were indexed by ISEM at 4, 7, 10, and 22 months, and concentration of BSV antigens in leaves was determined by ELISA 26 months after the start of the experiment.

Experiment 2. Twenty-one micropropagated plants of $2 \mathrm{AAB}$ cooking banana, 3 $\mathrm{ABB}$ plantain landraces, and 1 plantain hybrid TMPx 7002-1 were grown under screenhouse and coolroom conditions (Table 2). There were 4 plants of each cooking banana; 2 were grown in a screenhouse and other 2 in the coolroom in split plot design. Composite leaf samples from all plants were indexed by ISEM at 9 and 21 months from the beginning of experiment. After 24 months, the concentration of BSV antigens in leaves was determined by ELISA.

Experiment 3. Twenty-four 3-monthold micropropagated plants of a plantain hybrid TMPx 4698-1 with typical dark streak symptoms (Fig. 1A) were grown; 12 in the cool-room and the other 12 under screenhouse conditions in a split plot design. After 1 year, 6 plants were transferred from the coolroom to the screenhouse and vice versa. The concentration of BSV in
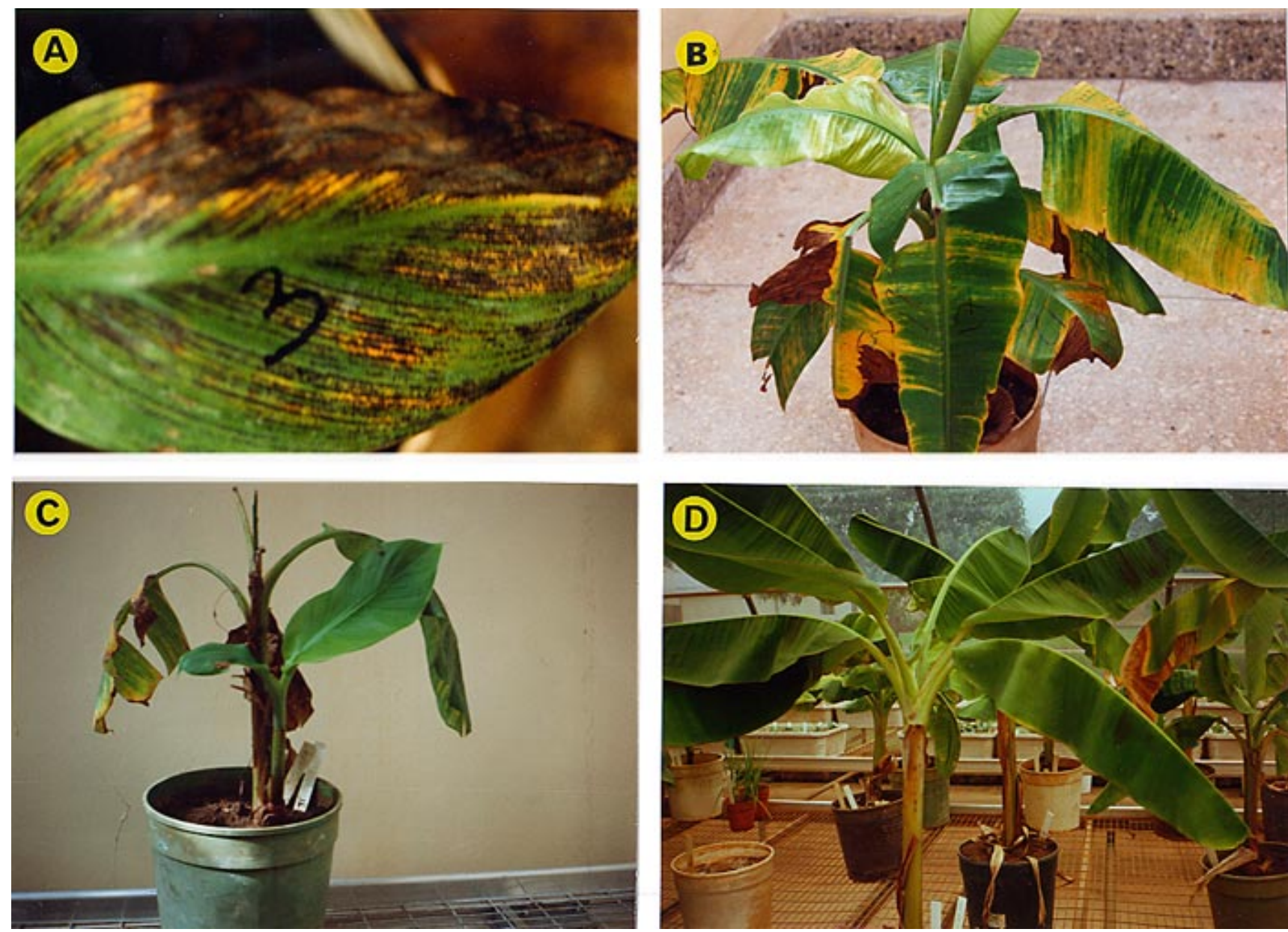

Fig. 1. Fluctuations in symptoms of banana streak badnavirus-infected plantain hybrids TMPx $4898-1$ grown in the screenhouse $\left(28\right.$ to $\left.35^{\circ} \mathrm{C}\right)$ and the coolroom $\left(22 \pm 2^{\circ} \mathrm{C}\right)$. (A) Dark streaks or necrotic areas under screenhouse conditions before temperature treatment; (B) golden yellow streaks or areas covering leaf lamina of a plant 6 months after transfer to the coolroom; (C) a sucker produced through pseudostem of a plant with severe symptoms; (D) recovery in symptoms after being grown in the screenhouse for 4 months. 
leaves was determined at 6, 12, and 15 months by ISEM and ELISA.

Data analysis. Wherever appropriate (experiment 3), the ASSI values were used to calculate the area under disease progress curves as described by Campbell and Madden (2). The ASSI, ISEM scores, and ELISA absorbance $\left(A_{405 \mathrm{~nm}}\right)$ were compared by analysis of variance, and means were separated by least significant difference (LSD) using Multstat software (20).

\section{RESULTS}

Symptom expression of BSV-infected plants at two temperature regimes varied by genotype. Plantain hybrids generally expressed more severe symptoms under coolroom conditions than those grown under screenhouse conditions, whereas most cooking bananas did not express symptoms under either temperature regime.

Experiment 1. Most micropropagated plants of TMPx 4698-1 and TMPx 548-9 grown under coolroom conditions expressed some streak symptoms (Table 1). Of the 2 genotypes, TMPx 4698-1 had the stronger symptoms. When asymptomatic but infected plants of all genotypes were moved from the coolroom to the screenhouse, most produced dark, discrete streaks at the basal portion of some mature leaves within 2 months. The original chlorotic spots of TMPx 4698-1, developed under coolroom conditions, remained until the leaf senesced, but dark streaks appeared on newly emerged leaves. After 4 months in the screenhouse, symptoms were less severe, with only mild streaks on a few leaves of TMPx 4698-1, TMPx 548-4, and TMPx 548-9. The streaks remained on TMPx 4698-1 throughout the observation period, whereas the symptoms became indiscernible in other genotypes.

Incidence of BSV and expression of symptoms are presented in Table 1. After growing for 4 months in the coolroom, 6 of the 31 plants (19\%) indexed BSV-positive by ISEM. In the follow-up test conducted at 7 months, $81 \%$ of the plants indexed positive, but only $20 \%$ of these plants expressed symptoms. After the second in- dexing (7 months), all mother plants, except 1 plant each of TMPx 1621-1 and TMBx 612-74, were transferred to the screenhouse. After 1 year in the screenhouse, only 4 of 28 plantlets (14\%) indexed BSV-positive by ISEM (Table 1). The 2 plants of TMPx 1621-1 and TMBx 612-74 left in the coolroom were indexed BSV-positive by ISEM but not by TASELISA. Four months after plants in the screenhouse were moved to cool-room, 13 of 23 plants $(57 \%)$ indexed BSV-positive by TAS-ELISA (Table 1 ).

Experiment 2. Plantlets of 5 cooking banana and 1 plantain hybrid TMPx 70021 did not express visible symptoms under either coolroom or screenhouse conditions until after 6 months, when chlorotic spots were observed on 1 to 2 leaves of 2 plants of TMPx 7002-1 under coolroom conditions. Those grown in the screenhouse expressed similar symptoms 2 to 3 weeks later which remained for only 2 to 3 weeks. Plants of cooking banana Agbagba grown under both coolroom and screenhouse conditions expressed chlorotic spots and discrete streaks. Some plants of Bluggoe, Cardaba, Mimi Abue, and Pelipita expressed dark, discrete symptoms under screenhouse conditions but indexed BSVnegative by ISEM (Table 2). In all cases, symptom expression was observed on only a few leaves and lasted for 4 to 5 weeks, although occasionally the symptoms reappeared on other leaves of some of these symptomatic plants after 5 to 9 weeks. The symptom severity score of these plants was always low (average less than 0.75).

The symptomatic plants of Agbagba, TMPx 7002-1, and 2 of the 4 non-symptomatic plants of Mimi Abue indexed BSV-positive by ISEM. On the other hand, plants of Cardaba and Bluggoe with mild streaks indexed BSV-negative by ISEM. After 1 year, ISEM examination of virus minipreps of leaf tissues indicated about a $40 \%$ increase in BSV-positive plants grown at $22^{\circ} \mathrm{C}$, but a decrease of about $27 \%$ in BSV-positive plants grown at 28 to $35^{\circ} \mathrm{C}$ (Table 2). Except for Bluggoe, at least 1 of the 2 plants of the other cooking banana grown at $22^{\circ} \mathrm{C}$ was indexed BSV- positive (Table 2). The 3 plants of Bluggoe, whether grown at 28 to $35^{\circ} \mathrm{C}$ (1 plant) or $22^{\circ} \mathrm{C}$ ( 2 plants), indexed BSV-negative both by ISEM and ELISA. BSV-indexing by ISEM was more sensitive than by ELISA (Table 2). Except for 1 plant of Mimi Abue grown at $22^{\circ} \mathrm{C}$, all the BSVpositive plants of cooking bananas and plantain landraces, including the hybrid TMPx 7002-1, had a low ISEM score (0 to 2) and a low absorbance value in ELISA (Table 2).

Experiment 3. When infected plants of TMPx 4698-1 with severe symptoms were grown under screenhouse and coolroom conditions, most newly emerged leaves of most of the plants exhibited whitish to yellow flecks after 3 to 4 weeks. Plants under coolroom conditions retained the original dark streak symptoms on mature leaves until senescence, but most of the newly emerged leaves produced characteristic yellow streaks, symptoms that covered the entire leaf lamina (Fig. 1B). After about 9 weeks, both symptom severity and the number of symptomatic leaves per plant increased under coolroom conditions but decreased under screenhouse conditions (data not shown). In the coolroom, all the leaves produced severe chlorotic spots or streak symptoms throughout the study period. Although severity varied with time; 2 of these plants also produced suckers through pseudostem (Fig. 1C). However, in similar experiments in the coolroom, pseudostem suckers were not produced in plants which indexed BSV-positive by ISEM.

When plants with severe leaf symptoms were moved from the coolroom to the screenhouse, there was a drastic reduction in symptom severity and relative concentration of BSV. After 8 weeks, most plants showed no symptoms (Fig. 1D) except for a few isolated chlorotic spots on 1 or 2 leaves of a few plants. In contrast, there was enhancement in symptom severity and concentration of BSV in plants moved from screenhouse to coolroom. Young or cigar leaves of all the plants moved from screenhouse to coolroom exhibited severe broken chlorotic streak symptoms about 2

Table 3. Change in average symptom severity index (ASSI) and relative concentration of banana streak badnavirus (BSV) in leaf tissues as measured by immunosorbent electronmicroscopy (ISEM) and enzyme-linked immunosorbent assay (ELISA) from plants of TMPx 4698-1 grown under screenhouse (SH, 28 to $35^{\circ} \mathrm{C}$ ) and coolroom (CR, $22 \pm 2^{\circ} \mathrm{C}$ ) conditions at Ibadan, Nigeria

\begin{tabular}{|c|c|c|c|c|c|c|c|c|c|}
\hline \multicolumn{2}{|c|}{ Growth conditions } & \multicolumn{3}{|c|}{ February 1996} & \multicolumn{3}{|c|}{ September 1996} & \multicolumn{2}{|c|}{ February 1997} \\
\hline $\begin{array}{l}\text { Initial } \\
\text { Aug } 95 \\
\end{array}$ & $\begin{array}{c}\text { After } \\
\text { transfer }\end{array}$ & $\begin{array}{l}\text { AUDPC of } \\
\text { ASSI } \pm \text { SE }\end{array}$ & $\begin{array}{c}\text { ISEM } \\
\text { score+SE }\end{array}$ & $\begin{array}{l}\text { Absorbancew } \\
\left(A_{405 \mathrm{~nm}}\right) \pm \mathrm{SE}\end{array}$ & $\begin{array}{l}\text { AUDPC of } \\
\text { ASSI } \pm \text { SE }\end{array}$ & $\begin{array}{c}\text { ISEM score } \\
\pm \mathrm{SE} \\
\end{array}$ & $\begin{array}{l}\text { Absorbance } \\
\left(A_{405 \mathrm{~nm}}\right) \pm \mathrm{SE}\end{array}$ & $\begin{array}{l}\text { AUDPC of } \\
\text { ASSI } \pm \text { SE }\end{array}$ & $\begin{array}{c}\text { Absorbance } \\
\left(A_{405 \mathrm{~nm}}\right) \pm \mathrm{SE}\end{array}$ \\
\hline $\mathrm{SH}$ &.$^{y}$ & $24.7 \pm 1.0$ & $0.3 \pm 0.1$ & $0.048 \pm 0.01$ & $13.5 \pm 1.4$ & $1.7 \pm 0.4$ & $0.408 \pm 0.02$ & $4.19 \pm 1.7$ & $0.170 \pm 0.03$ \\
\hline & $\mathrm{CR}$ & & & & $21.4 \pm 1.6$ & $4.0 \pm 0.0$ & $1.351 \pm 0.11$ & $8.76 \pm 1.4$ & $0.995 \pm 0.18$ \\
\hline CR & & $51.2 \pm 3.6$ & $4.0 \pm 0.0$ & $0.775 \pm 0.06$ & $31.5 \pm 3.2$ & $3.0 \pm 0.3$ & $0.752 \pm 0.14$ & $10.34 \pm 0.9$ & $1.225 \pm 0.19$ \\
\hline & $\mathrm{SH}$ & & 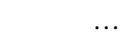 & & $13.3 \pm 1.0$ & $1.8 \pm 0.4$ & $0.361 \pm 0.08$ & $2.10 \pm 0.9$ & $0.028 \pm 0.01$ \\
\hline $\operatorname{LSD}^{\mathrm{z}}(0.05)$ & & 6.56 & 0.26 & 0.043 & 5.95 & 1.04 & 0.29 & 3.99 & 0.375 \\
\hline
\end{tabular}

${ }^{\mathrm{v}}$ Area under the disease progress curve (AUDPC) of ASSI per week was calculated as described by Campbell and Madden (2).

${ }^{w}$ Determined by double-antibody sandwich ELISA (B. E. L. Lockhart, unpublished).

${ }^{x}$ Determined by triple-antibody sandwich ELISA (15).

y $\ldots=$ not applicable.

${ }^{\mathrm{z}} \mathrm{LSD}=$ least significant difference. 
months after transfer. Thereafter, more severe symptoms were also observed on other newly developed leaves.

Results of ELISA- and ISEM-indexing of leaf tissues of TMPx 4898-1 at 6 months showed 16 times more BSV antigen in plants grown in the coolroom than in those grown in the screenhouse (Table 3). To confirm that the significant reduction in symptom severity and virus titer in plants grown under screenhouse conditions was caused by higher temperature, 6 of the 12 plants from both the coolroom or screenhouse were transferred to the other group (from coolroom to screenhouse or vice versa) at 9 months. Changes in symptom expression and relative concentration of BSV in leaf tissue were monitored for a further 6 months. After 2 months, ELISAindexing and ISEM examination of virus minipreps from the leaf tissues of the plants coming from $22^{\circ} \mathrm{C}$ indicated a high concentration of BSV virions, and about threefold higher BSV antigen in ELISA (Table 3). In contrast, virion concentration was lower in virus minipreps of plants transferred from $22^{\circ} \mathrm{C}$ to 28 to $35^{\circ} \mathrm{C}$, and the ELISA value was almost half of those at $22^{\circ} \mathrm{C}$.

\section{DISCUSSION}

The data presented in this paper show that the expression of BSV symptoms of most plantain hybrids (genome $\mathrm{AAB} \times$ AA) were more severe at $22^{\circ} \mathrm{C}$ but became indiscernible when grown at 28 to $35^{\circ} \mathrm{C}$. In an earlier study, Lockhart (10) observed that streak symptoms were more pronounced in leaves produced during high temperatures; however, data presented in this study show that change in temperature regime rather than absolute temperature was important for expression of severe symptoms. This change in symptoms was correlated with the concentration of virus, which was higher in tissues with severe symptoms and low or absent in tissues without symptoms. These results confirm an earlier report (14). However, symptom expression and virus concentration was variable depending upon genotypes. Most ABB cooking banana (cvs. Bluggoe, Cardaba, and Pelipita) and a $\mathrm{AAB}$ plantain landrace cv. Mimi Abue, which were BSVpositive by ISEM, occasionally expressed mild streaks at $22^{\circ} \mathrm{C}$ but not at 28 to $35^{\circ} \mathrm{C}$. BSV detection by ISEM in the asymptomatic tissues of these plants was generally low, but detection efficiency was significantly increased (from 23 to 64\%) after 2 years growth at $22^{\circ} \mathrm{C}$. These genotypes seldom show symptoms under field conditions (20), and all the micropropagated plants used in these studies were indexed BSV-negative by ISEM. These results suggest that some of the symptomless plants of $\mathrm{ABB}$ cooking bananas and $\mathrm{AAB}$ plantain landraces observed under field or screenhouse conditions are infected with BSV but index as negative, because the virus titer is below the limits of detection of available diagnostics.

BSV has yet not been eliminated from in vitro plantlets by thermotherapy $(3,12)$ but it may be possible to do so. In these experiments, when symptomatic plants were transferred to higher temperature conditions there was a decrease in the severity of symptoms and virus concentration, suggesting that there is potential for producing healthy plantlets. Plants from which the meristems are to be taken should be grown at higher temperatures prior to excision of the meristem, which may result in more virus-free plantlets.

Regular monitoring of experimental plants shows that temperature is the primary factor involved in severity of symptoms. Under natural conditions in Nigeria, different Musa genotypes develop various characteristic virus symptoms during the rainy (cooler) season, but symptoms are not observed during dry seasons. In a recent field study, there was a significant $(P$ $<0.004)$ negative relationship between symptom incidence and maximum temperature $\left(35^{\circ} \mathrm{C}\right)$, but the relationship between the severity of symptoms (1 to 3 rating scale) and temperature was not significant (4). Symptom expression also varies in the screenhouse in Nigeria between the dry and rainy seasons; more severe during the rainy season $\left(28\right.$ to $\left.30^{\circ} \mathrm{C}\right)$ than the dry seasons $\left(28\right.$ to $\left.35^{\circ} \mathrm{C}\right)$. These results contradict the initial observation of Lockhart (10) in Morocco, where more severe symptoms were observed in leaves produced during high temperature.

Currently, guidelines for the safe international movement of Musa germplasm suggest indexing and symptom observation be done over a 6 to 9 month period $(5,9)$ but do not specify the growing environment. Results presented here suggest that the plants should be grown in a cool environment (e.g., $22^{\circ} \mathrm{C}$ ) to stimulate symptom expression and to increase virus titer in plants that are infected. In plants suspected of being infected, any treatment that will increase virus-titer will make the confirmation of infection by diagnostics more reliable. The data in this study should provide valuable information for the quarantine screening of in vitro plantlets and virus diagnosis.

\section{ACKNOWLEDGMENTS}

We thank Jonathan Crouch, IITA, for his keen interest and encouragement, for providing plant materials used in these experiments, and for his suggestions to improve the initial draft of this manuscript; and our colleagues from the Plant Health Management Division, IITA, for their constructive criticism and suggestions.

\section{LITERATURE CITED}

1. Ahlawat, Y. S., Pant, R. P., Lockhart, B. E. L., Srivastava, M., Chakraborty, N. K., and Varma, A. 1996. Association of badnavirus with citrus mosaic disease in India. Plant Dis. 80:590-592.

2. Campbell, C. L., and Madden, L. V. 1990.
Introduction to Plant Epidemiology. John Wiley \& Sons, New York

3. Crouch, J. H. 1996. Safe movement of Musa germplasm in Central and West Africa. Pages 110-114 in: Plantain and Banana: Production and Research in West and Central Africa ( $\mathrm{R}$. Ortiz and M. O. Akoroda). Proceedings of a Regional Workshop, held at High Rainfall Station, Onne, Rivers State, Nigeria. International Institute of Tropical Agriculture (IITA), Ibadan, Nigeria.

4. Dahal, G., Hughes, J. d'A., Gauhl, F., Pasberg-Gauhl, C., and Nokoe, K. S. Symptomatology and temporal development of banana streak, a disease caused by banana streak badnavirus, under natural conditions in Ibadan, Nigeria. Acta Hortic. In press.

5. Diekmann, M., and Putter, C. A. J. 1996. FAO/IPGRI Technical Guidelines for the Safe Movement of Germplasm. No. 15. Musa. 2nd Edition. Food and Agriculture Organization of the United Nations, Rome/ International Plant Genetic Resources Institute, Rome.

6. FAO (Food and Agriculture Organization of the United Nations). 1992. FAO Yearbook, Production 1991, Vol. 45. FAO, Rome, Italy.

7. Gauhl, F., and Pasberg-Gauhl, C. 1995. Temporal dynamics of banana streak badnavirus (BSV) symptoms in Musa clones in southern Nigeria. Phytomedizin 25:27.

8. Harper, G., and Hull, R. 1996. Sequence analysis of banana streak virus. MusAfrica (Newsletter) 10:128.

9. Jones, D. R., and Lockhart, B. E. L. 1993. Banana Streak Disease. Fact Sheet No.1. Montpellier, ellier, France.

10. Lockhart, B. E. L. 1986. Purification and serology of a bacilliform virus associated with banana streak disease. Phytopathology 76:995-999.

11. Lockhart, B. E. L. 1990. Evidence for a double-stranded circular DNA genome in a second group of plant viruses. Phytopathology 80:127-131.

12. Lockhart, B. E. L. 1994. Banana streak virus. Pages 19-20 in: Compendium of Tropical Diseases, R. C. Ploelz, G. A. Zentmyer, W. T. Nishijima, K. G. Rohrbach, and H. D. Oar, eds. APS Press, St. Paul, MN, USA.

13. Lockhart, B. E. L., and Autrey, L. J. C. 1988. Occurrence in sugarcane of bacilliform virus related serologically to banana streak virus. Plant Dis. 72:230-233.

14. Lockhart, B. E. L., and Olszewski, N. E. 1993. Serological and genomic heterogeneity of banana streak badnavirus: implications for virus detection in Musa germplasm. Pages 105-113 in: Breeding Banana and Plantain for Resistance to Diseases and Pests, J. Genry, ed. Montpellier, France: INIBAP.

15. Ndoworo, T. C. R., and Lockhart, B. E. L. 1996. Improved serological methods for detecting banana streak virus. MusAfrica (Newsl.) 10:37.

16. Nweke, F., Njoku, J., and Wilson, G. F. 1988. Productivity and limitations of plantain (Musa spp. cv. AAB) production in compound gardens in South-eastern Nigeria. Fruits (Paris) 43:161-166.

17. Ortiz, 1996. The potential of AMMI analysis for field assessment of Musa genotypes to virus infection. HortScience 31:529-532.

18. Pasberg-Gauhl, C., Gauhl, F., Schill, P., Lockhart, B. E. L., Afreh-Nuamah, K., Osei, J. K., and Zuofa, K. 1996. First report of banana streak virus in farmers' fields in Benin, Ghana and Nigeria, West Africa. Plant Dis. 80:224.

19. Riechel, H., Belalcazar, S., Munera, G. Aarevano, E., and Narvaez, J. 1996. First report of the banana streak virus infecting 
plantains (Musa spp.) in Columbia. Plant Dis. 80:463.

20. Shane, W. W., Joyner, T. G., and Powell, C. C. 1990. Aplical, Randoma, and Multstat: three microcomputer utilities for managing field experiments. Plant Dis. 74:333-334.

21. Swennen, R., and De Langhe, E. 1989. Threats to the highland banana in Eastern Af- rica. Musarama 2:2-5.

22. Swennen, R., Vuylsteke, D., and Ortiz, R. 1995. Phenotypic diversity and patterns of variation in West and Central African plantains (Musa spp., AAB Group Musaceae). Econ. Bot. 49:320-327.

23. Vuylsteke, D. R. 1989. Shoot-tip culture for the propagation, conservation, and exchange of Musa germplasm. IBPGR Practical Manual for Handling Crop Germplasm in vitro 2. International Board of Plant Genetic Resources, Rome.

24. Vuylsteke, D. R., Chizala, C. T., and Lockhart, B. E. L. 1996. First report of banana streak virus disease in Malawi. Plant Dis. 80:224. 